\title{
ANALYSIS OF THE EFFICIENCY OF PRODUCTION OF WHOLE-MUSCLE TURKEY PRODUCTS WITH VEGETABLE SPRINKLES
}

\author{
Ivan F. Gorlov', Svetlana E. Bozhkova ${ }^{2}$, Anna R. Nichiporova ${ }^{2}$, \\ Yuri D. Danilov ${ }^{1 *}$, Marina I. Slozhenkina ${ }^{1}$, Evgeniya A. Romanenko ${ }^{1}$ \\ ${ }^{1}$ Volga Region Scientific Research Institute of Meat-and-Milk Production and Processing, Volgograd, Russia \\ ${ }^{2}$ Volgograd State Technical University, Volgograd, Russia
}

\begin{abstract}
Keywords: whole-muscle baked goods, turkey meat, Glimalask, chickpeas, sesame, paprika, vegetable crumbles, fortified foods
\end{abstract}
\begin{abstract}
Human health is largely determined by the nature, level and structure of nutrition. A promising direction in the development of new food products is the expansion of the base of used ingredients used to partially replace meat raw materials with vegetable ones, in order to maximize the saturation of products with nutrients that contribute to the maintenance of normal life of the consumer. The use of new food ingredients contributes to the actual task set by the State policy in the field of healthy eating - expanding the range of enriched and functional food products. The work is devoted to the study of baked whole-muscle products using turkey meat and vegetable dressing as sources of high protein content, which solves the problem of deficiency of this component in the diet. A recipe for brine with the addition of the food additive "Glimalask", which has a complex effect on the products under study, has been presented. The evaluation of quality indicators of finished products has been carried out, the article presents the results of a comparative analysis of baked whole-muscle turkey meat products, calculations of the product cost price. The comparative analysis has shown that, in comparison with the control sample, the baked whole-muscle products from turkey meat with vegetative dressing have improved physical and chemical properties, outstanding organoleptic characteristics, the yield of the product increases by 9.0-12.0\%, depending on the formulation. Differences in the dynamics of microbial growth in the experimental and control samples were insignificant, the vegetable dressing helps to slow the growth of microorganisms on the surface of the product. The presented baked whole-muscle turkey meat products using optimized brine and vegetable sprinkles of chickpeas, sesame and paprika are recommended to a wide range of consumers of different age groups.
\end{abstract}

For citation: Gorlov, I. F., Bozhkova, S. E., Nichiporova, A. R., Danilov, Y. D., Slozhenkina, M. I., Romanenko, E. A. (2021). Analysis of the efficiency of production of whole-muscle turkey products with vegetable sprinkles. Theory and Practice of Meat Processing, 6(4), 343-353. https://doi.org/10.21323/2414-438X-2021-6-4-343-353

\section{Funding:}

This work was carried out under the grant of the Russian Science Foundation 21-16-00025 SSI NIIMMP.

\section{Introduction}

Today, issues related to healthy and rational nutrition are becoming more and more popular. At present, much attention is paid to human nutrition - new food products regularly appear on the shelves, and consumers are increasingly paying attention to their composition and nutritional value [1]. Human health is largely determined by the nature, level and structure of nutrition, which has a number of serious violations. Lack of essential substances in nutrition is one of the most important problems in Russia. One of the directions of the State policy in the field of healthy nutrition of Russians is to increase domestic production of food raw materials and food products, including enriched products and products with functional and therapeutic properties [2]. Unbalanced nutrition is a pressing problem in our country. Modern lifestyle forces people to eat on the go, which leads to various diseases [3].

Nutrition has the most significant impact on human health and life. Lack of vitamins, macro- and microele- ments in the diet negatively affects the body. Proper nutrition contributes to the prevention of many diseases, including nutritional diseases, and also contributes to increasing the average human life expectancy $[4,5]$. The creation of meat products designed to treat and prevent disease is a progressive trend in the food industry that has extremely important practical and social significance [6].

To improve the quality of food products, their appearance, structure, storability, for their enrichment are currently used in many ways. These include, for example, the use of various food additives, vitamin complexes, dietary fiber of plant origin, salt mixtures, etc. Today, the priority area of food technology is the production of enriched meat products characterized by high nutritional and biological value. Innovative food products made from natural raw materials, not only provide consumers with a healthy diet, but also guarantee the producers an increased competitive status and access to the world class market. One of the modern trends in expanding the range and improving the quality of food

Copyright (c) 2021, Gorlov et al.This is an open access article distributed under the terms of the Creative Commons Attribution 4.0 International License (http://creativecommons. org/licenses/by/4.0/), allowing third parties to copy and redistribute the material in any medium or format and to remix, transform, and build upon the material for any purpose, even commercially, provided the original work is properly cited and states its license. 
products is the integrated use of raw materials of animal and plant origin [7].

For the production of enriched product turkey meat can be used very effectively. As a product of animal origin, meat contains animal protein, which is most fully assimilated by the body, as well as many nutrients necessary for the body [6].

Turkey meat is considerably superior to duck and goose meat in terms of high-protein content. It is a source of such amino acids as tryptophan, lysine, arginine. Low enough fat content. Turkey meat is rich in B vitamins, niacin and riboflavin, which has medicinal value, as well as fat-soluble vitamins $A, D$. Using such meat in the diet does not lead to an increase in blood cholesterol. Turkey is rich in various minerals, especially calcium and phosphorus. At the same time, the presence of collagen and elastin in the proteins of poultry leads to stiffness of the product and difficulty in digestion. Therefore, the creation of products with specified properties by introducing cheap plant materials into the product makes it possible to reduce the final cost of production [8].

Enrichment, or the process of optimizing raw materials and then the final product, is an important tool for functional and specialized nutrition [9]. Currently, the use of food additives of plant origin is widely used in the technology of meat products, which not only expand the range, but also increase the biological value, improve the organoleptic characteristics of the finished food products. Also, the use of plant ingredients leads to optimization of functional and technological properties of the product [10].

The relevance of this study is to study and develop new technologies and recipes for the food industry, which are aimed at expanding the range of products and improving its quality. The work is devoted to the study of baked whole muscle products using turkey meat and vegetable crumbles as sources of high protein content; the development of the recipe for brine optimized composition for the production of baked product, as well as analyzing the effectiveness of the use of crumbles of vegetable raw materials in the production of this product. The development of the method of production of baked meat product according to the recipes using regional raw materials is also very relevant and appropriate in terms of rational use of raw materials of food industry [11-13].

The aim of the work is to study the technology and qualitative characteristics of whole-muscle baked turkey products with a vegetable sprinkling. The objectives of the study are to select ingredients, formulation development, brine injection of meat raw materials (turkey) and the selection of vegetable raw materials for the sprinkling of baked products, optimization of technological regimes, evaluation of quality parameters of the product.

\section{Objects and methods}

The work was carried out on the basis of the department "Technologies of food production" of Volgograd State Technical University and complex analytical labora- tory of the "Volga Region Scientific Research Institute of Meat-and-Milk Production and Processing" and consisted of the following stages: selection and preparation of raw materials, production of experimental samples of whole baked turkey products, conducting organoleptic, physical and chemical and microbiological studies to assess the quality of the products.

The research scheme is shown in Figure 1. The objects of the research work were samples of whole baked turkey products, which were produced using the above components with salt and spices.

The control sample was a baked turkey product, injected with brine of standard composition. Experimental samples were produced using brine with the food additive "Glimalask": sample № $1-$ baked turkey product with a mixture of black and white sesame; sample № 2 - baked turkey product with a spicy coating; sample № 3 - baked whole-muscle turkey product with a coating of extruded chickpeas.

Optimization of the formulation of the developed product was carried out using the Excel program included in the package MS Office 2019. Production of the studied samples of baked product was carried out in accordance with the current regulatory and technical documentation (GOST 34159-2017)'. Sampling and preparation of samples for laboratory studies were carried out according to a unified methodology in accordance with the requirements of GOST R51447-99 (ISO 3100-1-91) ${ }^{2}$. Determination of organoleptic characteristics was carried out according to the requirements of GOST R53159-2008 (ISO 4120:2004) ${ }^{3}$, GOST R53161-2008 (ISO 5495:2005) ${ }^{4}$. Mass fraction of fat was determined by extraction of total fat with a mixture of chloroform and ethyl alcohol in a filtering separating funnel; protein by mineralization of the sample by Kjeldahl and photometric measurement of color intensity of indophenol blue, which is proportional to the amount of ammonia in the mineralizer. Determination of microbiological indicators the number of mesophilic aerobic, facultatively anaerobic microorganisms - in accordance with the requirements of GOST 54354-20115; nutrient composition - using tabular data from the Guide to the chemical composition of Russian food products edited by I. M. Skurikhin; energy value calculation method in accordance with the standards of SanERR2.3.2.1078.016.

\footnotetext{
${ }^{1}$ GOST 34159-2017 "Products from meat. General specifications". Moscow: Standartinform, 2017. - 12 p. (In Russian)

${ }^{2}$ GOST R51447-99 "Meat and meat products. Methods of primary sampling". Moscow: Standartinform, 2001. - 6 p. (In Russian)

${ }^{3}$ GOST R53159-2008 "Organoleptic analysis - Methodology — Triangle test". Moscow: Standartinform, 2010. - 16 p. (In Russian)

${ }^{4}$ GOST R53161-2008 "Organoleptic analysis - Methodology - Paired comparison test”. Moscow: Standartinform, 2010. - 20 p. (In Russian)

${ }^{5}$ GOST 54354-2011 "Meat and meat products. General requirements and methods of microbiological testing". Moscow: Standartinform, 2013. - 38 p. (In Russian)

${ }^{6}$ Sanitary and epidemiological rules and regulations SanERR2.3.2. 1078-01 "Hygienic requirements for the safety and nutritional value of food products". Retrieved from https://docs.cntd.ru/document/901806306/titles/ LSES2M Accessed August 15, 2021. (In Russian)
} 


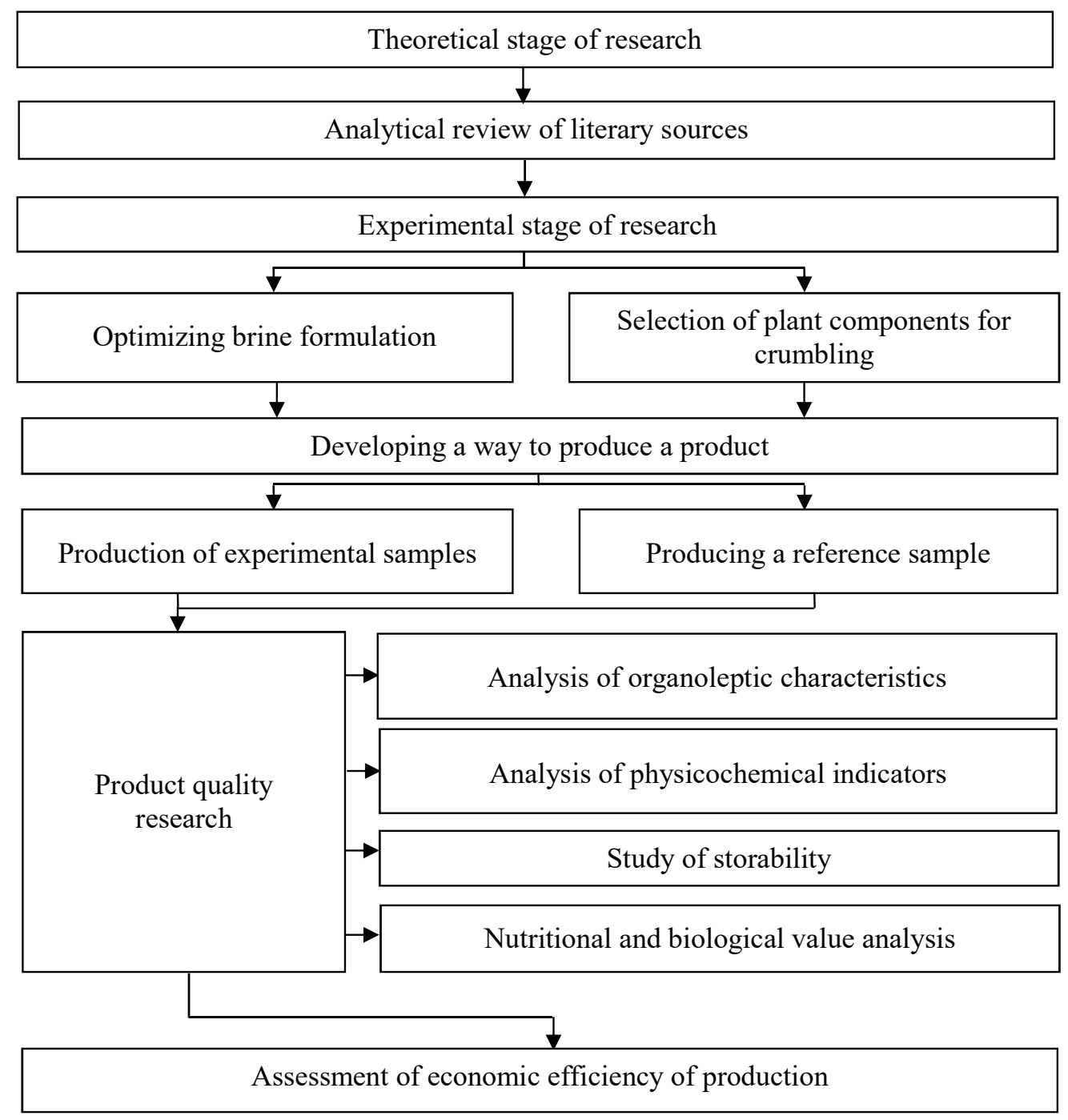

Figure 1. Scheme of work

Mineral composition of experimental samples was determined on spectrophotometer "Kvant-2AT" (KORTEK, Russia); amino acid composition - analyzer ARACUS Amino Acid Analyzer (MembraPure GmbH, Germany); vitamins - using device "Fluorat-02-5M" (Lumex, Russia).

The equipment for sample production is presented in Table 1.

\section{Table 1. List of equipment used for sample production}

\begin{tabular}{|c|c|c|c|}
\hline $\begin{array}{l}\dot{0} \\
\stackrel{0}{0} \\
\text { on }\end{array}$ & Name of equipment & Type, brand & $\begin{array}{l}\text { Manufacturer, } \\
\text { country }\end{array}$ \\
\hline 1 & Brine preparation unit & Techtron + CM 300 & Techtron, Russia \\
\hline 2 & Injector & Dorit PSM 10 & Dorit, Germany \\
\hline 3 & Vacuum Massager & IPCS -107-200 (H) & Russia \\
\hline 4 & Industrial blender & $\begin{array}{c}\text { Sirman ORIONE } \\
\text { FIVE VV }\end{array}$ & Sirman, China \\
\hline 5 & Universal heat chamber & $\begin{array}{l}\text { Thermostar } \\
\text { SLT } 2000\end{array}$ & $\begin{array}{l}\text { Schaller, } \\
\text { Germany }\end{array}$ \\
\hline 6 & Packaging vacuum line & Multivak R-105 & $\begin{array}{l}\text { Multivak, } \\
\text { Germany }\end{array}$ \\
\hline 7 & Electronic table scales & CAS AD-10H & CAS, South Korea \\
\hline
\end{tabular}

The study materials were processed by variation statistics according to Plokhinsky N. A. using the "Microsoft Office" program package on a PC [14]. The difference in the indices was considered reliable at $\mathrm{P}>0.95$.

\section{Results and discussion}

\section{Sample production}

In the course of this research the technology of baked turkey product was developed. Whole-muscle roast meat product is a meat product made from different parts of the carcass (half carcass) in the form of cuts or individual muscles, pieces of meat subjected to salting in the manufacturing process, bringing it to readiness for consumption through heat treatment. The technology of the baked product includes the following stages: reception of raw materials, injection of brine, massaging, ageing, molding, heat treatment, cooling, quality control, packaging, labeling and sales.

As a result of the optimization of the formulation was developed a way of producing a balanced product, using brine for injection, the formulation of which is presented in Table 2. The recipe of the product is presented in Table 3. 
Table 2. Recipe of brines

\begin{tabular}{|l|c|c|}
\hline \multicolumn{1}{|c|}{ Brine components } & \multicolumn{2}{c|}{ Consumption, $\mathrm{kg}$} \\
\cline { 2 - 3 } & $\begin{array}{c}\text { for the } \\
\text { control } \\
\text { sample }\end{array}$ & $\begin{array}{c}\text { for } \\
\text { experimental } \\
\text { samples }\end{array}$ \\
\hline Water & 94.25 & 94.2 \\
\hline Phosphate complex & 1.0 & 1.0 \\
\hline Nitrite salt & 2.0 & 2.0 \\
\hline Soy protein isolate & 2.25 & 2.25 \\
\hline Granulated sugar & 0.5 & 0.5 \\
\hline Nutritional supplement "Glimalask» & - & 0.05 \\
\hline UTOFO & 100.0 & 100.0 \\
\hline
\end{tabular}

In the brine used in the manufacture of test samples of the product, added a complex food additive "Glimalask". The food additive is a complex of organic acids: aminoacetic acid (glycine), ascorbic acid and malic acid. Recipe of the food additive contains per $100 \mathrm{~kg}$ of product: glycine $-80 \mathrm{~kg}$, ascorbic acid $-12 \mathrm{~kg}$, malic acid $-8 \mathrm{~kg}^{7}$. The expected effects of the food additive "Glimalask": firstly, reducing the $\mathrm{pH}$ of the brine, which will inhibit the growth of putrefactive microorganisms in the salting process. Secondly, obtaining a product enriched with the above organic acids, with improved organoleptic characteristics (soft consistency, taste, aroma). Thirdly, reducing the $\mathrm{pH}$ of the brine will reduce the active acidity of whole-muscle baked products, which will increase the shelf life of the finished product.

\section{Table 3. Product Recipe}

\begin{tabular}{|c|c|c|c|c|c|}
\hline Ingredient name & 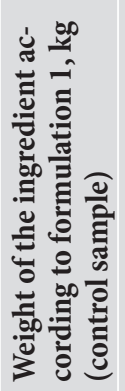 & 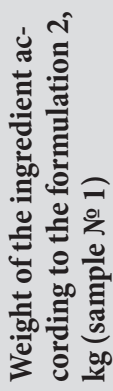 & 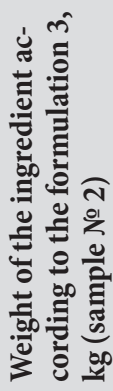 & 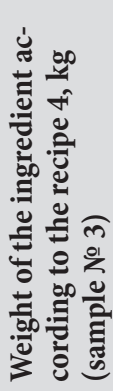 & 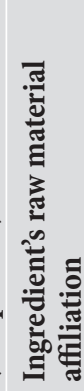 \\
\hline $\begin{array}{l}\text { Turkey. Brisket, } \\
\text { (boneless meat) }\end{array}$ & 100.0 & 100.0 & 100.0 & 100.0 & meat \\
\hline $\begin{array}{l}\text { Sprinkle with a mixture } \\
\text { of black and white } \\
\text { sesame }\end{array}$ & - & 10.0 & - & - & plant \\
\hline Spicy sprinkles & - & - & 8.0 & - & plant \\
\hline Chickpea shells & - & - & - & 10.0 & plant \\
\hline Brine & 10.0 & 10.0 & 10.0 & 10.0 & - \\
\hline
\end{tabular}

For the production of baked turkey product the following method of salting was used: injecting meat raw material with brine in an amount of $10 \%$ of the weight of unsalted raw material, massaging in a massager with a drum rotation frequency of $18 \mathrm{r} / \mathrm{min}$ for 15 minutes. Salt has a positive effect on the yield of the finished product. As a result, the meat has an increased water-binding capacity, which markedly improves the consumer properties of the finished product.

${ }^{7}$ Gorlov I. F., Polyakov V. A. Food additive. Patent RF, no.2519777, 2014. (In Russian)
As an additional food ingredient, crumbles are used. It gives the product an attractive appearance, taste and aroma. To apply crumbles used breading drum. Its work consists of shaking pieces of meat in a mixture for crumbling. Sprinkles are applied in an amount of $7-10 \%$ to the mass of unsalted raw meat.

Thermal processing is baking. Baking the product at $100-120^{\circ} \mathrm{C}$ for $1-2$ hours. When the temperature in the center of the product reaches $70-72{ }^{\circ} \mathrm{C}$, the product is considered ready. The next step is cooling, which is carried out in special chambers until the temperature reaches $8{ }^{\circ} \mathrm{C}$ in the thickness of the product.

\section{Features of the used sprinkles}

\section{Sesame seeds}

Particular attention should be paid to the coating. Sesame seeds are high in protein (Table 4). Easily digestible vegetable protein accounts for about 19\%. Sesame is a source of essential and substitutable amino acids: $36 \%$ and $27 \%$ per 100 grams of protein, respectively. Thus the content of all the amino acids found in the seeds (in 100 grams) exceeds 10\% of the daily requirement. In sufficient quantities in sesame are amino acids such as valine, tryptophan and isoleucine. Arginine and glycine are the most abundant among the substitutable amino acids [15].

Also in abundance, sesame includes dietary fiber, which, in turn, contributes to the removal of toxins from the body. Fiber can bind fat molecules and improve organ motility [16].

Sesame seeds are high in fatty acids, including polyunsaturated omega- 6 fatty acids (namely linoleic acid): 100 g contains $214 \%$ of the daily requirement. Omega- 6 and omega-3 in sesame have a ratio of 5.7:1, this value is the best for the human body $[17,18]$. At the same time, sesame seeds are also rich in monounsaturated omega- 9 fatty acid, up to 19 grams in 100 grams. This fatty acid protects blood vessels from the formation of cholesterol plaques and is a prevention of atherosclerosis, which suggests the use of a sample with this coating as a gerodietic product [19].

Table 4. Nutritional value of sesame seeds

\begin{tabular}{|l|c|c|}
\multicolumn{1}{|c|}{ Indicator } & Quantity, g/100 g & $\begin{array}{c}\text { Percentage } \\
\text { of recommended daily } \\
\text { allowance }\end{array}$ \\
\hline Proteins & $19.40 \pm \mathbf{0 . 0 8}$ & $21.09 \%$ \\
\hline Fats & $48.70 \pm 0.15$ & $72.69 \%$ \\
\hline Carbohydrates & $12.20 \pm \mathbf{0 . 1 0}$ & $\mathbf{8 . 7 0 \%}$ \\
\hline Dietary fiber & $\mathbf{5 . 6 0 \pm 0 . 1 2}$ & $\mathbf{2 8 . 0 \%}$ \\
\hline
\end{tabular}

* - the average vitamin and mineral levels for adults were used for the calculation.

Sesame seeds influence hormone levels through their significant phytosterol content (campesterol, beta-sitosterol, and stigmasterol). Their content reaches $714 \mathrm{mg}$, which is $1298 \%$ of the recommended daily allowance. They regulate estrogen levels in their excess or deficiency [20].

Sesame has antioxidant properties. Having in its composition lecithin, sesamin and squalene, it protects tissues from 
environmental influences. These substances also stimulate the growth of collagen and elastin fibers [20].

Sesame seeds have beneficial properties due to their high content of vitamins A, B, C and E. Niacin (PP) is involved in carbohydrate and lipid metabolism. Thiamine $\left(\mathrm{B}_{1}\right)$ and riboflavin $\left(B_{2}\right)$ in sesame have beneficial effects on the nervous system [21]. These vitamins support nerve cell function. The vitamin content of sesame is shown in Table 5.

Table 5. Vitamin content of sesame per 100 grams

\begin{tabular}{|l|c|c|}
\hline \multicolumn{1}{|c|}{ Indicator } & Quantity, mg & $\begin{array}{c}\text { Percent } \\
\text { of the recommended } \\
\text { daily rate }\end{array}$ \\
\hline Vitamin $B_{1}$ & $0.79 \pm 0.09$ & $46.9 \%$ \\
\hline Vitamin $B_{2}$ & $0.79 \pm 0.09$ & $39.5 \%$ \\
\hline Vitamin $B_{3}$ & $0.10 \pm 0.006$ & $24.3 \%$ \\
\hline Vitamin B $_{6}$ & $4.52 \pm 0.14$ & $22.6 \%$ \\
\hline Vitamin $B_{9}$ & $2.44 \pm 0.12$ & $16.3 \%$ \\
\hline Vitamin E & $0.25 \pm 0.008$ & $12.5 \%$ \\
\hline
\end{tabular}

* - the average vitamin and mineral levels for adults were used for the calculation.

100 grams of sesame seeds contain a significant amount of essential minerals (Table 6). It is in the composition of sesame that calcium is best absorbed [21,22]. All these micronutrients characterize the high benefits of white and black sesame for the body.

Table 6. Mineral content of sesame per 100 grams

\begin{tabular}{|l|c|c|}
\hline \multicolumn{1}{|c|}{ Indicator } & Quantity, $\mu \mathrm{g}$ & $\begin{array}{c}\text { Percent } \\
\text { of the recommended } \\
\text { daily allowance }\end{array}$ \\
\hline Silicon & $199110 \pm 1250$ & $663.3 \%$ \\
\hline Copper & $4100 \pm 150$ & $410.6 \%$ \\
\hline Nickel & $190 \pm 35$ & $126.7 \%$ \\
\hline Manganese & $2460 \pm 220$ & $123.0 \%$ \\
\hline Calcium & $1070000 \pm 45000$ & $113.6 \%$ \\
\hline
\end{tabular}

* - the average vitamin and mineral levels for adults were used for the calculation.

\section{Spicy Sprinkles}

The spice coating includes paprika. This spice is the dried and ground fruits of the mildly spicy capsicum annuum pepper. Paprika is valuable not only for its characteristic taste and aroma, but also for its unique composition of biologically active substances [23]. The nutritional value of paprika is presented in Table 7.

Table 7. Nutritional value of dried paprika per 100 grams

\begin{tabular}{|l|c|c|}
\multicolumn{1}{|c|}{ Indicator } & Quantity, $\mathrm{g}$ & $\begin{array}{c}\text { Percent } \\
\text { of the recommended } \\
\text { daily allowance }\end{array}$ \\
\hline Proteins & $15.4 \pm 0.12$ & $18.19 \%$ \\
\hline Fats & $13.80 \pm 0.20$ & $16.74 \%$ \\
\hline Carbohydrates & $23.20 \pm 0.22$ & $20.50 \%$ \\
\hline
\end{tabular}

* - the average vitamin and mineral levels for adults were used for the calculation.
The consumption of such a spice has a positive effect on the work of organs and tissues, this is achieved due to the content of many different biologically active substances [24]. It is important to note that paprika, which is produced from sweet varieties of pepper, when used in various dishes is safe for the body even in large quantities.

Paprika stimulates the immune system, is characterized by high content of carotene and vitamin C. Paprika has a favorable effect on the circulatory system, helps to prevent blood clotting and purifies it from excess cholesterol, is used to prevent thrombosis, which is an important element in the prevention of acute heart disease. Spice affects blood vessels and heart muscle and has a general strengthening effect [25].

Paprika normalizes metabolic processes in the body. Spice promotes not only faster but also more effective absorption of useful substances. Spice prevents gastrointestinal disorders.

This spice contains large amounts of lutein, which makes it especially beneficial for the eyes. Spice keeps the retina in a healthy state, has a beneficial effect in violation of the integrity and structure of the optic nerve. Paprika prevents damage to the cells of the eye, due to oxidative stress, reduces the accumulation of some pigments that provoke the development of maculodystrophy [25].

\section{Chickpeas and chickpea extrudate}

The application of chickpea extrudate wrappings leads to increased nutritional and biological value, increased shelf life, reduced caloric content, and reduced losses during thermal processing of finished products [26]. Chickpeas have about $28 \%$ (in terms of dry matter) of protein. The extrudate has a very high water-binding capacity (WBC), which in turn leads to an increase in fat-retention capacity (FTR) and antibacterial activity. The nutritional value of chickpeas is presented in Table 8.

Table 8. Nutritional value of chickpeas per 100 grams

\begin{tabular}{|l|c|c|}
\hline \multicolumn{1}{|c|}{ Indicator } & Quantity, $g$ & $\begin{array}{c}\text { Percent } \\
\text { of the recommended } \\
\text { daily allowance }\end{array}$ \\
\hline Protein & $20.10 \pm 0.80$ & $26.4 \%$ \\
\hline Fats & $4.32 \pm 0.16$ & $7.7 \%$ \\
\hline Carbohydrates & $46.16 \pm 0.58$ & $21.1 \%$ \\
\hline Dietary fiber & $9.90 \pm 0.90$ & $49.5 \%$ \\
\hline
\end{tabular}

* - the average vitamin and mineral levels for adults were used for the calculation.

Chickpeas contain nicotinic and ascorbic acids. It is also rich in Omega-3 and Omega-6 acids [27]. It is worth noting the high starch content - up to $43 \%$. It contains about $60 \%$ of high quality carbohydrates, about $5 \%$ of minerals (Table 9) and various vitamins such as $A, K, B_{1}, B_{2}, B_{4}, B_{6}$, $\mathrm{B}_{9}, \mathrm{E}[28]$. 
Table 9. Mineral content of chickpeas

\begin{tabular}{|l|c|c|}
\multicolumn{1}{|c|}{ Indicator } & Quantity, mg & $\begin{array}{c}\text { Percent } \\
\text { of the recommended } \\
\text { daily allowance }\end{array}$ \\
\hline Potassium & $968.0 \pm 9.0$ & $38.7 \%$ \\
\hline Calcium & $193.0 \pm 7.0$ & $19.3 \%$ \\
\hline Magnesium & $126.0 \pm 5.0$ & $31.5 \%$ \\
\hline Phosphorus & $444.0 \pm 8.0$ & $55.5 \%$ \\
\hline Manganese & $3.0 \pm 0.2$ & $107.0 \%$ \\
\hline Silicon & $92.0 \pm 5.0$ & $306.7 \%$ \\
\hline
\end{tabular}

* — the average vitamin and mineral levels for adults were used for the calculation.

Chickpea consumption helps to regulate blood sugar levels, which indicates the benefits for people suffering from diabetes. The regular use of the product improves the digestive processes and the state of the gastrointestinal tract. Chickpeas are digested long enough, while giving a large amount of energy to the human body.

To reduce the fat content of the crumbling mixture, as well as possible rancidity, you can use chickpea whole-grain flour as a raw material for extrusion. Due to the fact that the vegetable raw material is rich in carbohydrates and protein, a Maillard reaction is possible; extrusion reduces the lysine content of the product [29]. In turn, such legumes as chickpeas are rich in this amino acid. The use of chickpea extrudate from whole-grain flour as a breading mixture makes it possible to use it in meat products subject to heat treatment, in dietary nutrition, provides a reduction of losses during heat treatment, increases the shelf life, and increases the nutritional and biological values of the finished products [30].

\section{Organoleptic evaluation of the product}

As a result of research, the formulation of brine and product samples were optimized. Prototypes were developed with subsequent organoleptic evaluation (Table 10), which showed high consumer qualities. Tasting evaluation was carried out (Table 11). Profilogram of organoleptic indicators of experimental samples is shown in Figure 2.

In terms of consistency, color on the cut, as well as appearance, the samples of whole-muscle baked products do not differ from each other; the exception may be the use of different sprinkles. Tasting evaluation of the products

Table 10. Organoleptic indicators

\begin{tabular}{|c|c|c|c|c|}
\hline Item name & Control sample & $\begin{array}{l}\text { Baked turkey product with } \\
\text { sesame sprinkles }\end{array}$ & $\begin{array}{l}\text { Baked turkey product with } \\
\text { spicy sprinkles }\end{array}$ & $\begin{array}{l}\text { Baked turkey product with } \\
\text { chickpea sprinkles }\end{array}$ \\
\hline $\begin{array}{l}\text { 1. Shape, } \\
\text { surface }\end{array}$ & $\begin{array}{l}\text { Shape peculiar to part of the } \\
\text { carcass or other configuration } \\
\text { according to the casings, nets, } \\
\text { films and molds used. Surface } \\
\text { clean, without slips, broth } \\
\text { and fatty swellings, without } \\
\text { mucus, mold }\end{array}$ & $\begin{array}{l}\text { Shape peculiar to part of the } \\
\text { carcass or other configuration } \\
\text { according to the casings, nets, } \\
\text { films and molds used. Surface } \\
\text { clean, without slips, broth } \\
\text { and fatty swellings, without } \\
\text { mucus, mold }\end{array}$ & $\begin{array}{l}\text { Shape peculiar to part of the } \\
\text { carcass or other configuration } \\
\text { according to the casings, nets, } \\
\text { films and molds used. Surface } \\
\text { clean, without slips, broth } \\
\text { and fatty swellings, without } \\
\text { mucus, mold }\end{array}$ & $\begin{array}{l}\text { Shape peculiar to part of the } \\
\text { carcass or other configuration } \\
\text { according to the casings, nets, } \\
\text { films and molds used. Surface } \\
\text { clean, without slips, broth } \\
\text { and fatty swellings, without } \\
\text { mucus, mold }\end{array}$ \\
\hline $\begin{array}{l}\text { 2. Structure, } \\
\text { consistency }\end{array}$ & $\begin{array}{l}\text { Dense. The meat is tender, } \\
\text { easy to cut }\end{array}$ & $\begin{array}{l}\text { Dense. The meat is tender, } \\
\text { easy to cut }\end{array}$ & $\begin{array}{l}\text { Dense. The meat is tender, } \\
\text { easy to cut }\end{array}$ & $\begin{array}{l}\text { Dense. The meat is tender, } \\
\text { easy to cut }\end{array}$ \\
\hline $\begin{array}{l}\text { 3. Taste and } \\
\text { smell }\end{array}$ & $\begin{array}{l}\text { A pronounced taste and } \\
\text { odor typical of this product, } \\
\text { moderately salty }\end{array}$ & $\begin{array}{l}\text { The distinct taste and smell of } \\
\text { added food additives, sesame, } \\
\text { moderately salty }\end{array}$ & $\begin{array}{l}\text { The distinct taste and smell } \\
\text { of added food additives, } \\
\text { paprika, moderately salty }\end{array}$ & $\begin{array}{l}\text { The distinct taste and smell } \\
\text { of added food additives, } \\
\text { chickpeas, moderately salty }\end{array}$ \\
\hline $\begin{array}{l}\text { 4. Color } \\
\text { on the cut }\end{array}$ & $\begin{array}{l}\text { Uniformly colored muscle } \\
\text { tissue of light pink color }\end{array}$ & $\begin{array}{l}\text { Uniformly colored muscle } \\
\text { tissue of light pink color }\end{array}$ & $\begin{array}{l}\text { Uniformly colored muscle } \\
\text { tissue of light pink color, } \\
\text { without gray spots }\end{array}$ & $\begin{array}{l}\text { Uniformly colored muscle } \\
\text { tissue of light pink color, } \\
\text { without gray spots }\end{array}$ \\
\hline
\end{tabular}

Table 11. Tasting evaluation of organoleptic characteristics

\begin{tabular}{|c|c|c|c|c|c|c|c|c|}
\hline \multirow[b]{2}{*}{ Indicator } & \multicolumn{8}{|c|}{ Characteristic } \\
\hline & Control sample & score & $\begin{array}{l}\text { Baked turkey product } \\
\text { with sesame sprinkles }\end{array}$ & score & $\begin{array}{l}\text { Baked turkey product } \\
\text { with spicy sprinkles }\end{array}$ & score & $\begin{array}{l}\text { Baked turkey product } \\
\text { with chickpea sprinkles }\end{array}$ & score \\
\hline Consis-tency & $\begin{array}{l}\text { Dense. The meat is } \\
\text { tender, easy to cut }\end{array}$ & 5 & $\begin{array}{l}\text { Dense. The meat is } \\
\text { tender, easy to cut }\end{array}$ & 5 & $\begin{array}{l}\text { Dense. The meat is } \\
\text { tender, easy to cut }\end{array}$ & 5 & $\begin{array}{l}\text { Dense. The meat is } \\
\text { tender, easy to cut }\end{array}$ & 5 \\
\hline $\begin{array}{l}\text { Color on the } \\
\text { cut }\end{array}$ & $\begin{array}{l}\text { Uniformly colored } \\
\text { muscle tissue of light } \\
\text { pink color }\end{array}$ & 4 & $\begin{array}{l}\text { Uniformly colored } \\
\text { muscular tissue of light } \\
\text { pink color. No gray } \\
\text { spots }\end{array}$ & 5 & $\begin{array}{l}\text { Uniformly colored } \\
\text { muscle tissue of light } \\
\text { pink color }\end{array}$ & 4 & $\begin{array}{l}\text { Uniformly colored } \\
\text { muscular tissue of light } \\
\text { pink color. No gray } \\
\text { spots }\end{array}$ & 5 \\
\hline Taste & Moderately salty & 2 & $\begin{array}{l}\text { Moderately salty, with a } \\
\text { distinct sesame flavor }\end{array}$ & 4 & Moderately salty, spicy & 5 & $\begin{array}{l}\text { Moderately salty, with a } \\
\text { nutty flavor }\end{array}$ & 5 \\
\hline Smell & $\begin{array}{l}\text { Fresh meat product, } \\
\text { with no extraneous } \\
\text { odor }\end{array}$ & 3 & $\begin{array}{l}\text { Fresh meat product, } \\
\text { nutty, sweet smell }\end{array}$ & 5 & $\begin{array}{l}\text { Fresh meat product, } \\
\text { with a spicy smell }\end{array}$ & 5 & $\begin{array}{l}\text { Fresh meat product, } \\
\text { with a pronounced } \\
\text { legume flavor }\end{array}$ & 4 \\
\hline Appea-rance & $\begin{array}{l}\text { Shape peculiar to the } \\
\text { part of the carcass } \\
\text { Surface clean, without } \\
\text { slips, clots, broth } \\
\text { and fatty swellings, } \\
\text { without mucus, mold }\end{array}$ & 3 & $\begin{array}{l}\text { Shaped peculiar part } \\
\text { of the carcass with a } \\
\text { uniform sprinkling of } \\
\text { black and white sesame } \\
\text { seeds. Without mucus } \\
\text { and mold }\end{array}$ & 5 & $\begin{array}{l}\text { Shaped peculiar part } \\
\text { of the carcass with a } \\
\text { coating of a mixture of } \\
\text { spicy herbs, paprika. } \\
\text { No mucus, no mold }\end{array}$ & 5 & $\begin{array}{l}\text { Shaped like a part } \\
\text { of the carcass with a } \\
\text { sprinkling of chickpea } \\
\text { extrudate. No mucus, } \\
\text { no mold }\end{array}$ & 5 \\
\hline
\end{tabular}




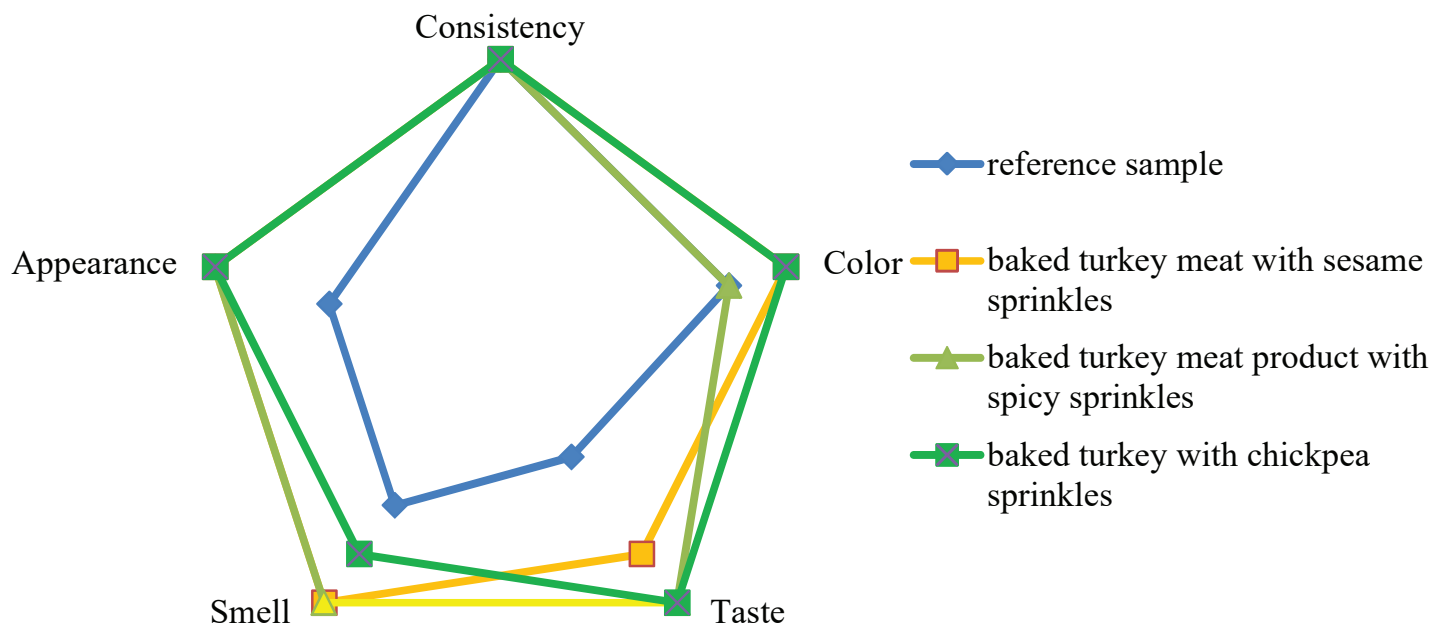

Figure 2. Profilogram of tasting evaluation of experimental samples

showed that the use of sprinkles has a positive effect on the perception of products: compared with the control, where there is no sprinkles, whole turkey meat baked products with sprinkles acquire a presentable appearance of the delicacy, the smell and taste become more expressive due to the added ingredients: sesame seeds, spicy herbs, paprika, chickpea extrudate (Figure 2).

\section{Physical and chemical parameters of the finished product}

In terms of physical and chemical parameters, the product must meet the requirements specified in Table 12 .

As can be seen from the table, the content of sodium chloride, nitrite and phosphate does not change with the addition of vegetable dressing to the recipe of baked whole-muscle products. Sesame, chickpea and paprika do not contain these substances. Sesame and chickpea extrudate crumbles increased the protein content of the finished product, with the chickpea crumbled sample having the highest protein content. The chickpea extruded sample ranked first among the samples in terms of fat content. These variations are directly related to the type of crusting used: chickpea is rich in protein, while sesame is high in fatty acids.

The results of determining the moisture-binding capacity (MBC) of the finished products are shown in Figure 3. Baked whole-muscle products with extruded chickpea sprinkles had the highest MBC; the control sample had the lowest water-binding capacity. Consequently, the use of the sprinkles contributes to a noticeable increase in the water-binding capacity.

Table 12. Physico-chemical parameters of baked whole-muscle products

\begin{tabular}{|c|c|c|c|c|}
\hline \multirow[b]{2}{*}{ Indicator } & \multicolumn{4}{|c|}{ Rate per position, $\%$} \\
\hline & Control sample & $\begin{array}{l}\text { Baked turkey meat with } \\
\text { sesame sprinkles }\end{array}$ & $\begin{array}{l}\text { Baked turkey meat product } \\
\text { with spicy sprinkles }\end{array}$ & $\begin{array}{l}\text { Baked turkey with } \\
\text { chickpea sprinkles }\end{array}$ \\
\hline Mass fraction of protein & $20.5 \pm 0.3$ & $22.0 \pm 0.6^{*}$ & $20.2 \pm 0.3$ & $26.0 \pm 0.4^{\star * *}$ \\
\hline Mass fraction of fat & $12.0 \pm 0.5$ & $13.0 \pm 0.3$ & $12.0 \pm 0.5$ & $12.2 \pm 0.6$ \\
\hline $\begin{array}{l}\text { Mass fraction of table salt } \\
\text { (sodium chloride) }\end{array}$ & $3.0 \pm 0.01$ & $3.0 \pm 0.01$ & $3.0 \pm 0.01$ & $3.0 \pm 0.01$ \\
\hline Mass fraction of nitrite & $0.004 \pm 0.0001$ & $0.004 \pm 0.0001$ & $0.004 \pm 0.0001$ & $0.004 \pm 0.0001$ \\
\hline $\begin{array}{l}\text { Mass fraction of added } \\
\text { phosphorus (in terms of } \mathrm{P}_{2} \mathrm{O}_{5} \text { ) }\end{array}$ & $0.4 \pm 0.005$ & $0.4 \pm 0.005$ & $0.4 \pm 0.005$ & $0.4 \pm 0.005$ \\
\hline
\end{tabular}

${ }^{\star}-\mathrm{P}>0.95 ;{ }^{* *}-\mathrm{P}>0.99 ;{ }^{* *}-\mathrm{P}>0.999$ - reliability of the difference compared to the control sample.

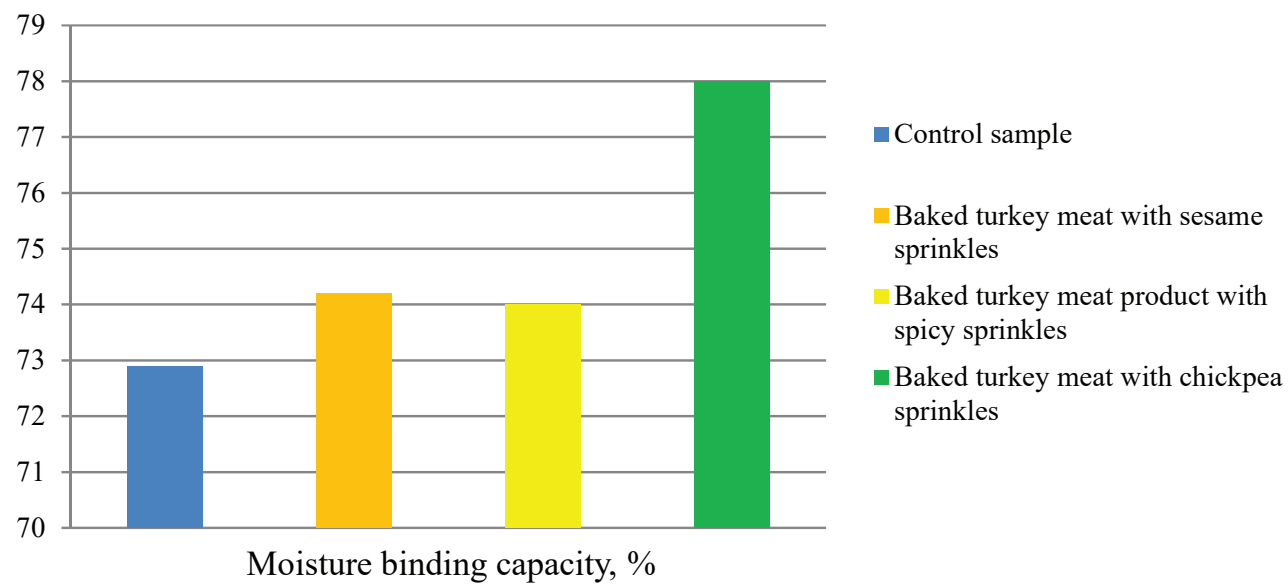

Figure 3. Results of determining the moisture-binding capacity of whole-muscle baked products 


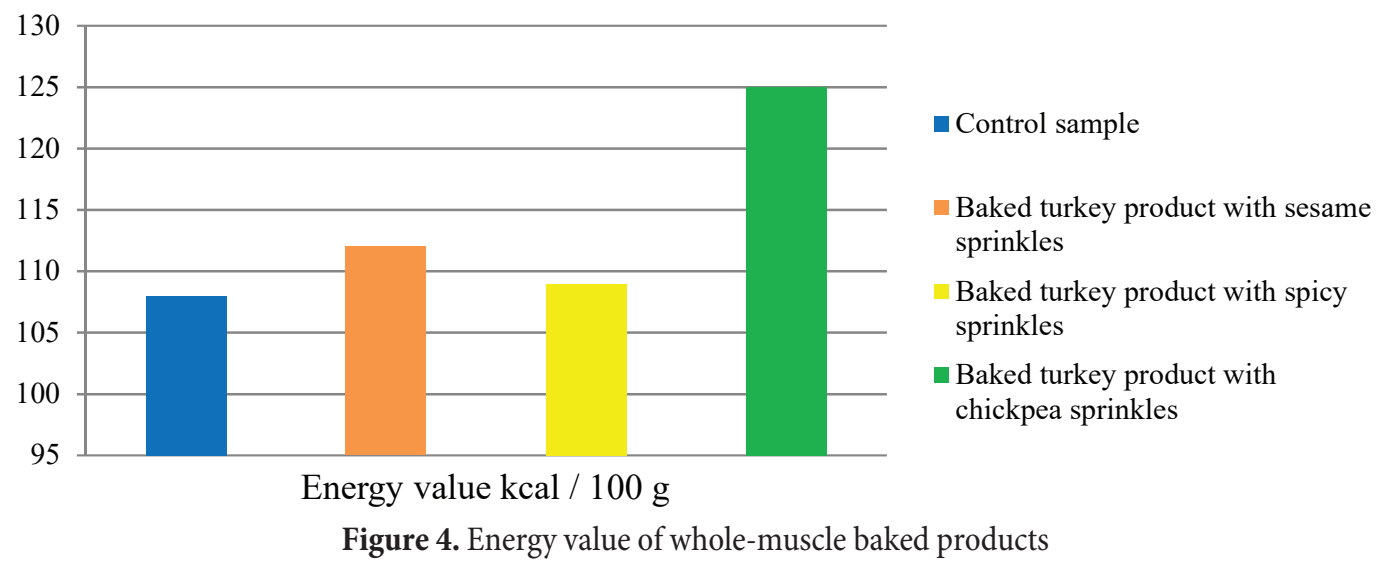

\section{Energy value}

The results of calculating the energy value of the developed products are shown in Figure 4. As can be seen from the above data, the sample with a coating of extruded chickpeas has the highest caloric value. This is explained by the fact that chickpea extrudate contains more protein than raw meat. The increase in carbohydrate content also contributes to the increase in the energy value of the sample using chickpea sprinkles.

\section{Product yield}

During sample production, we evaluated the yield of the finished product after brine injection, crumbling, and heat treatment operations. The results are presented in Table 13. More clearly the growth of the yield of finished products depending on the used brine and crumbling is shown in Figure 5.

In the production of the assortment of baked wholemuscle turkey meat products the same parameters of salting of raw meat and heat treatment were used. The difference was in the composition of the brine and dressing used. The histogram shows that the control sample had the lowest yield, while the sample using brine with "Glimalask" food additive and extruded chickpea crumbles had the highest yield. The difference in yield between the product using the different types of sprinkles is minimal and is only $3 \%$. Consequently, the use of a combination of the food additive "Glimalask" as part of the brine and plant crumbles contributes to an increase in the yield of the finished product.

Table 13. Effect of heat treatment on mass yield of samples

\begin{tabular}{|c|c|c|c|}
\hline Sample & 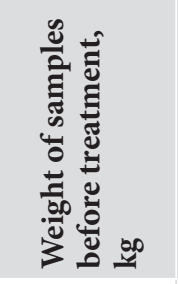 & 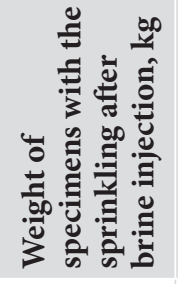 & 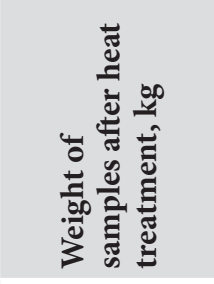 \\
\hline Control sample & $100.0 \pm 0.01$ & $109.4 \pm 0.50$ & $105.0 \pm 2.50$ \\
\hline $\begin{array}{l}\text { Baked turkey meat } \\
\text { with sesame sprinkles }\end{array}$ & $100.0 \pm 0.01$ & $118.4 \pm 0.70$ & $114.0 \pm 2.80^{* \star *}$ \\
\hline $\begin{array}{l}\text { Baked turkey meat } \\
\text { product with spicy } \\
\text { sprinkles }\end{array}$ & $100.0 \pm 0.01$ & $116.8 \pm 0.30$ & $116.0 \pm 1.90^{* * *}$ \\
\hline $\begin{array}{l}\text { Baked turkey meat with } \\
\text { chickpea sprinkles }\end{array}$ & $100.0 \pm 0.01$ & $119.2 \pm 0.90$ & $117.0 \pm 3.20^{* * *}$ \\
\hline
\end{tabular}

${ }^{*}-\mathrm{P}>0.95$; ${ }^{* *}-\mathrm{P}>0.99$; ${ }^{* *}-\mathrm{P}>0.999-$ reliability of the difference compared to the control sample.

\section{Product storage}

At the final stage, the dynamics of microbial growth during storage of baked whole-muscle turkey meat products were studied by counting the quantity of mesophilic aerobic and facultative anaerobic microorganisms (QMA\&OAMO) [31].

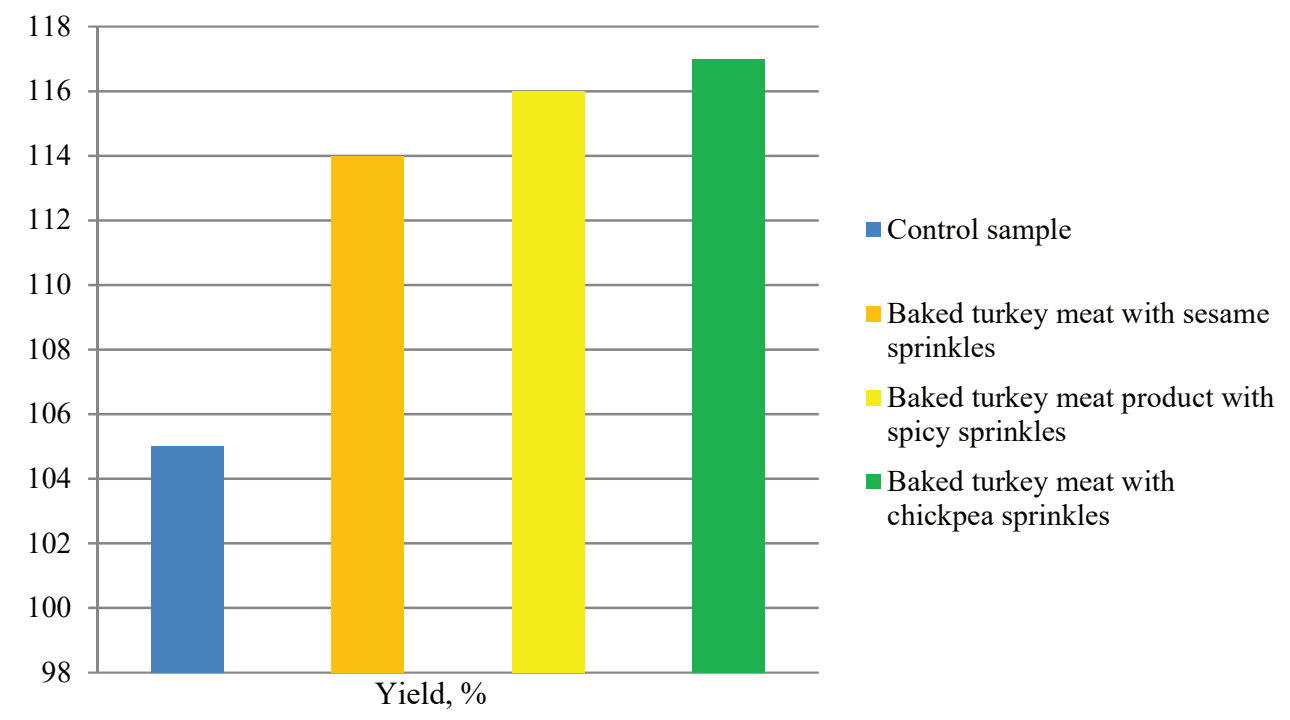

Figure 5. Yield of finished products 


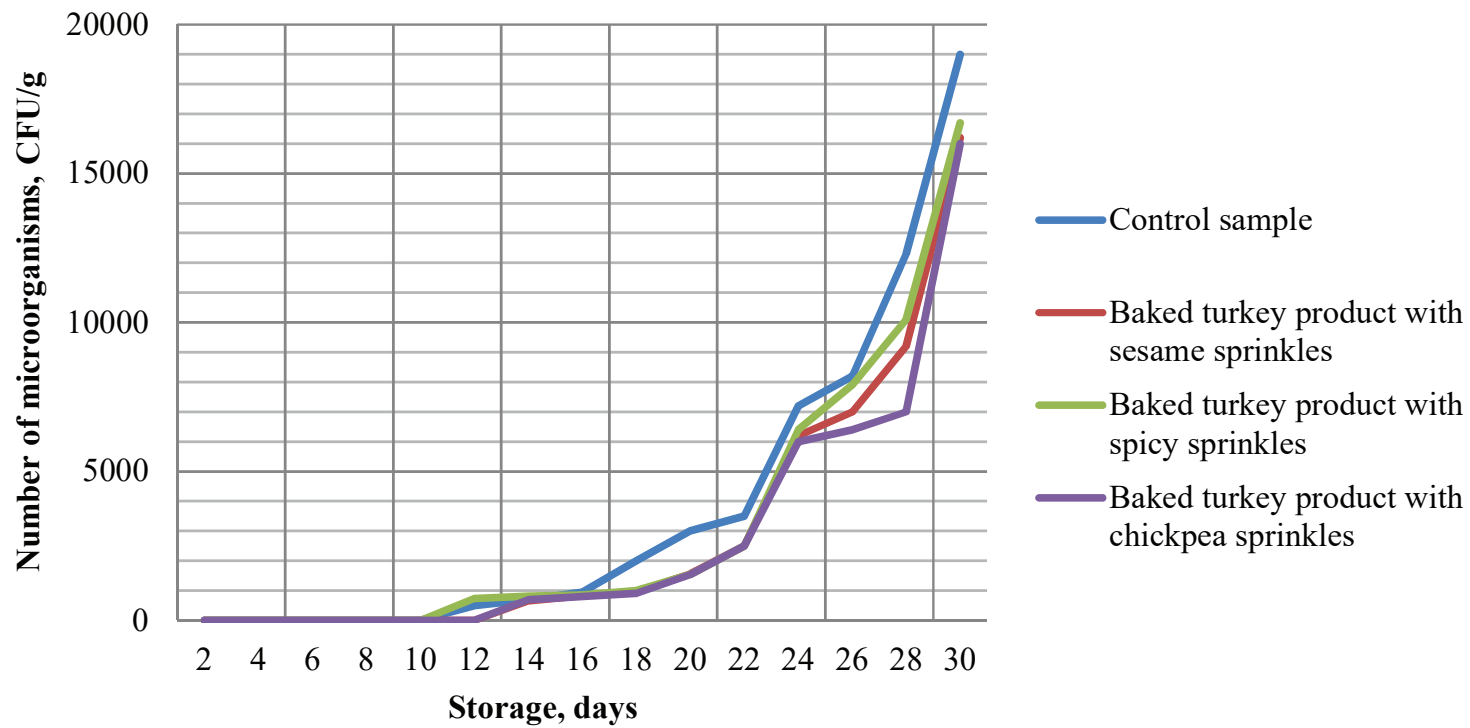

Figure 6. Dynamics of growth of QMA\&OAMO indicator during storage

The growth of the total number of bacteria in the control and experimental samples had a similar character, which is clearly shown in Figure 6. However, the control sample showed accelerated growth of QMA\&OAMO indicator, and at day 30 had the highest value.

Increasing the preservation period of the quality of experimental samples of the product due to the presence of crumbling and food additive "Glimalask" in the composition of the brine. As is known, during storage on the surface of the product is the development of bacteria, and as a consequence - spoilage of products and at its consumption in food - infectious diseases, poisoning, etc. [32]. The content of antioxidants in the casing can slow the rate of oxidative processes and, accordingly, reduce the amount of oxidation products. At the same time, due to the hygroscopic properties of the sprinkles, moisture does not accumulate on the surface of the product, which reduces the likelihood of active bacterial development.

\section{Calculation of the cost of the product}

The cost of production was calculated, as well as the recommended retail price (RRP) for the studied products (Table 14). The purpose of this stage was to determine how much more expensive the products would be if the brine of optimized composition and plant fillings were used in the production.

When calculating the cost of production, we relied on the results of the output of finished products. The recommended retail price was obtained taking into account the possible manufacturer's markup of $40 \%$. Naturally, the control sample will have the lowest recommended price, since the production of the samples under study did not involve replacing meat raw materials as the most expensive ingredient with cheaper components. The increase in price is mainly due to the use of the complex food additive "Glimalask" in the brine. The most expensive product is whole-muscle turkey product with sesame sprinkles.

Table 14. Calculation of the cost and recommended price per $1 \mathrm{~kg}$ of finished product

$$
\begin{array}{c|c}
\text { Name of raw material } & \begin{array}{c}
\text { Price per kg, } \\
\text { rubles }
\end{array}
\end{array}
$$

\section{Quantity, kg}

Control sample
Baked turkey product with chickpea sprinkles

\section{Turkey (brisket)}

\section{Phosphate complex}

Nitrite salt $\left(0,6 \% \mathrm{NaNO}_{2}\right)$

Soy protein isolate

\section{Sugar sand}

Nutritional supplement «Glimalask»

Water

Black and white sesame mixture

\section{Spice sprinkle mix}

Chickpeas extruded

Raw material costs, rubles

The cost of the finished product, rubles / $\mathrm{kg}$

RRP, rubles/kg

\section{Main raw materials}

316

110

120

200

49

1000

15

198

210

64

\section{Spices and materials}

0.01

\begin{tabular}{|c|c|}
\hline 0.01 \\
\hline
\end{tabular}

0.005

$-$

0.9425

-

-

-

338.4

322.3

451.2
Baked turkey
product with
spicy sprinkles

\begin{tabular}{c|c}
$\begin{array}{c}\text { Baked turkey } \\
\text { product with } \\
\text { sesame sprinkles }\end{array}$ & $\begin{array}{c}\text { Baked turkey } \\
\text { product with } \\
\text { spicy sprinkles }\end{array}$
\end{tabular}

1.0

1.0

\begin{tabular}{|c|}
\hline 0.01 \\
\hline 0.02 \\
0.0225 \\
0.005 \\
0.05 \\
0.942 \\
\hline
\end{tabular}

0,1

$-$

$-$

408.7

358.1

501.4

$-$

0,08

-

405.2

349.3

489.1
1.0

0.01

0.02

0.0225

0.005

0.05

0.942

$-$


The cheaper product is the extruded chickpea crumble. However, it is still recommended to keep all three positions of baked turkey meat products with sprinkles, since the main objective of our study was to expand the range of enriched food products using a combination of meat and vegetable raw materials. In addition, the recommended prices for these products are much lower than the market average, the value of which is 710.0 rubles $/ \mathrm{kg}$.

\section{Conclusion}

In the course of the study an optimized composition of brine for meat raw material injection was developed. The use of brine for injecting the product containing the complex food additive "Glimalask" as well as flakes of vegetable raw materials in the technology of whole muscle baked products increases the functional and technological properties, product yield, the content in the product of nutrients necessary for the body, improves organoleptic indicators and moisturebinding capacity.

During the study of organoleptic characteristics of the experimental samples it was found that the best results have the samples with the use of sprinkles from a mixture of sesame and chickpea. The use of sprinkles in the recipe contributed to improving the appearance, as well as the taste and aromatic properties of the product. The use of brine of optimized composition allowed to improve the consistency of the product, color on the cut.

The produced samples according to physical and chemical indices correspond to the norms established by scientific and technical documentation. The sample with chickpea sprinkles has the highest energy value, its value is $125 \mathrm{kcal} / 100 \mathrm{~g}$ of product, this is a consequence of increased content of proteins, fats and carbohydrates in the finished product. The increased protein content in the experimental samples with sprinkles is achieved through the rational use of vegetable raw materials with high protein content. The presence of crumbles allows us to enrich the products with vitamins such as A, K, B group, fatty acids and dietary fiber.

Samples with sesame and spice crumbles do not have great differences in terms of energy value, and are 111.7 and $108.9 \mathrm{kcal} / 100 \mathrm{~g}$ of product, respectively. The energy value of the control sample $-107.7 \mathrm{kcal} / 100 \mathrm{~g}$. The control sample does not contain carbohydrates in its composition. Compared with the control sample, the yield of the products increased by $9.0-12.0 \%$, the maximum increase was noticed when using chickpea extrudate filling.

The best storability is in the samples with chickpea and sesame extrudates, the products with spice extrudates are slightly inferior to their QMA\&OAMO indices. The decrease in the rate of oxidative processes due to the content of antioxidants in the sprinkles, as well as its hygroscopic properties, can increase the preservation period of the quality of the finished product.

The average market price of turkey products is 710 rubles per kg. The production of this product is economically profitable, as manufactured products have a lower recommended retail price. The RRP of three experimental samples is $501.4,489.1$ and 472.5 rubles per kg, respectively.

The produced samples of the product are recommended to a wide range of consumers of different age groups, which represents an important part in the implementation of the product. Thus, the development of technology of baked turkey product with the use of multicomponent brine of optimized composition and vegetable dressing contributes to the expansion of the range of enriched meat products, reducing the cost, has practical and social significance.

\section{REFERENCES}

1. Glazkova, I. V., Sargisyan, V. A., Sidorova, Yu. S., Maso, V. K., Kochetkova, A. A. (2017). The main stages of the efficacy evaluation of foods for special dietary uses. Food Industry, 12, 8-11. (In Russian) 2. Schnetter, B., Sepulveda, N., Bravo, S., Grunert, K. G., Hueche, C. (2018). Consumer acceptance of a functional processed meat product made with different meat sources. British Food Journal, 120(2), 424-440. https://doi.org/10.1108/BFJ-04-2017-0211 3. Gorlov, I. F., Slozhenkina, M. I., Danilov, Y. D., Mosolova, N. I., Zlobina, E. Y. et al. (2019). Research of storage terms of products functional appointment with addition of vegetable ingredient. Indo American Journal of Pharmaceutical Sciences, 06(08), 14992-14997. https://doi.org/10.5281/zenodo.3373770

4. Novikova, M. V., Dudnik, T. L. (2012). Development of specialized products of gerodietetic nutrition. Service in Russia and Abroad, 2(29), 2-10. (In Russian)

5. Alvarez-Orti, M., Gomez, R., Pardo, J. E. (2009). Manufacture of red line meat products with higher colour stability and improved visual attractiveness. Journal of Food, Agricultural and Environment, $7(1), 16-18$.

6. Birch, C. S., Bonwick, G. A. (2019). Ensuring the future of functional foods. International Journal of Food Science and Technology, 54(5), 1467-1485. https://doi.org/10.1111/ijfs.14060

7. Flores, M., Piornos, J. A. (2021) Fermented meat sausages and the challenge of their plant-based alternatives: A comparative review on aroma-related aspects. Meat Science, 182, Article 108636. https://doi.org/10.1016/j.meatsci.2021.108636

8. Khramova, V. N., Surkov D. I., Gorlov, I. F., Timofeeva, A. D., Korotkova, A. A. (18-20 November, 2020). Increasing amino-acid score of chopped semi-finished products. IOP Confer- ence Series: Earth and Environmental Science, 677(3), Article 32052. Krasnoyarsk, Russia. https://doi.org/10.1088/17551315/677/3/032052

9. Chernukha, I. M., Fedulova, L. V., Dydykin, A. S. (2014). Safe and useful products as the main factor determining the quality of life. Vsyo o myase, 2, 20-22. (In Russian)

10. Gorlov, I. F., Slozhenkina, M. I., Bozhkova, S. E., Pilipenko, D. N., Natyrov, A. K. et al. (2019). Meat and vegetable pate: optimization of functional and processing properties and quality parameters. Indo American Journal of Pharmaceutical Sciences, 06(08), 1499815005. https://doi.org/10.5281/zenodo.3373778

11. Lisitsyn, A.B., Chernukha, I.M., Lunina, O.I. (2018). Modern trends in the development of the functional food industry in Russia and abroad. Theory and Practice of Meat Processing, 3(1), 2945. https://doi.org/10.21323/2414-438X-2018-3-1-29-45 12. Osadchenko, I. M., Gorlov, I. F., Kharchenko, 0. V., Nikolayev, D. V. (2017). Efficient seed treatment method for cereal crops by soaking in electro-activated solutions. Bulletin of the Altai State Agricultural University, 7(153), 36-39. (In Russian)

13. Gorlov, I. F., Bozhkova, S. E., Danilov, Y. D., Anisimova, E. Y., Mosolova, N. I., Starodubova, J. V. (18-20 June, 2020). Analysis of efficiency of production of sausage products using non-traditional vegetable raw materials. IOP Conference Series: Earth and Environmental Science, 548(8), Article 082032. Krasnoyarsk, Russia. https://doi.org/10.1088/1755-1315/548/8/082032

14. Plohinskiy, N. A. (1970). Biometriya. MSU Publishing House, 1970. (In Russian)

15. Martinchik, A. N. (2011). Nutritional value of sesame seeds. Voprosy Pitaniia, 80(3), 41-43. (In Russian) 
16. Elleuch, M., Bedigian, D., Roiseux, O., Besbes, S., Blecker, C., Attia, H. (2011). Dietary fibre and fibre-rich by-products of food processing: Characterisation, technological functionality and commercial applications. Food Chemistry, 124(2), 411-421. https://doi.org/10.1016/j.foodchem.2010.06.077

17. Kashkinbai, K. U., Altayuly, S., Kuzcova, A. E., Smagulova, M. E. (2019). Development of technology of boiled sausage products using sesame seeds. Scientific review. Pedagogical sciences, 3-3, 52-56. (In Russian)

18. Fennema, R.O. (1995). Food Chemistry. Third Edition. Marcel Dekker, Basel, 1995.

19. Karamatov, I. J., Istamova, D. M. (2017). Promising medicinal plant sesame. Biology and Integrative medicine, 214-227.

20. Pisoschi, A. M., Pop, A., Georgescu, C., Turcus, V., Olah, N. K., Mathe, E. (2018). An overview of natural antimicrobials role in food. European Journal of Medicinal Chemistry, 143, 922-935. https://doi.org/10.1016/j.ejmech.2017.11.095

21. Sallam, K. I., Abd-Elghany, S. M., Imre, K., Morar, A., Herman, V., Hussein, M. A. et al. (2021) Ensuring safety and improving keeping quality of meatballs by addition of sesame oil and sesamol as natural antimicrobial and antioxidant agents. Food Microbiology, 99, Article 103834. https://doi.org/10.1016/j.fm.2021.103834 22. Zhuang, X., Han, M., Kang, Z.-L., Wang, K., Bai, Y., Xu, X.-L. et al. (2016). Effects of the sugarcane dietary fiber and pre-emulsified sesame oil on low-fat meat batter physicochemical property, texture, and microstructure. Meat Science, 113, 107-115. https://doi.org/10.1016/j.meatsci.2015.11.007

23. Koncsek, A., Kruppai, L., Helyes, L., Bori, Z., Daood, H. G. (2016). Storage stability of carotenoids in paprika from conventional, organic and frost-damaged spice red peppers as influenced by illumination and antioxidant supplementation. Journal of Food Processing and Preservation, 40(3), 453-462. https://doi. org/10.1111/jfpp.12623

24. Martin-Sanchez, A. M., Ciro-Gomez, G., Vilella-Espla, J., BenAbda, J., Perez-Alvarez, J. T., Sayas-Barbera, E. (2014). Influence of fresh date palm co-products on the ripening of a paprika added dry-cured sausage model system. Meat Science, 97(2), 130-136. https://doi.org/10.1016/j.meatsci.2013.12.005

25. Śtursa, V., Diviš, P., Pořizka J. (2018). Characteristics of paprika samples of different geographical origin. Potravinarstvo Slovak Journal of Food Sciences, 12(1), 254-261. https://doi. org/10.5219/902

26. De Pilli, T., Fiore, A. G., Guiliani, R., Derossi, A., Severini, K. (2011). Functional food produced by extrusion: cooking technology. Chapter in a book: Food Production: New Research, Nova Press, 2011.

27. McClements, D. J. (2018). Recent developments in encapsulation and release of functional food ingredients: delivery by design. Current Opinion in Food Science, 23, 80-84. https://doi. org/10.1016/j.cofs.2018.06.008

28. Dzhaboeva, A., Byazrova, O., Tedtova, V., Baeva, Z., Kokaeva, M. (18-19 March, 2021). The use of chickpea flour in the minced meat products formula. E3S Web of Conferences, 262, Article 01026. Nalchik, Russia. https://doi.org/10.1051/e3sconf/202126201026

29. Ali, S., Singh, B., Sharma, S. (2017). Development of highquality weaning food based on maize and chickpea by twinscrew extrusion process for low-income populations. Journal of Food Process Engineering. 40(3), Article e12500. https://doi. org/10.1111/ifpe.12500

30. Kulikov, D., Kolpakova, V., Slozhenkina, M., Ulanova, R., Chumikina, L. (18-24 August, 2020). Biotechnological process for producing protein products from chickpeas with a high biological value. 20th International Multidisciplinary Scientific GeoConference SGEM, Albena, Bulgaria. https://doi.org/10.5593/ sgem2020/6.1/s25.023

31. Danilov, Y. D., Gorlov, I. F., Slozhenkina, M. I., Zlobina, E. Y. (2019). Extruded chickpea and wheat in technology of sausage products of enhanced biological value. Progress in Nutrition, 21(3), 610-619. https://doi.org/10.23751/pn.v21i3.7331

32. de W. Blackburn, C. (2006). Food spoilage microorganisms. Woodhead Publishing, 2006.

\section{AUTHOR INFORMATION}

Ivan F. Gorlov, Doctor of agricultural sciences, Professor, Academician of RAS, Scientific supervisor, Volga Region Scientific Research Institute of Meat-and-Milk Production and Processing. 6 Rokossovsky str., Volgograd, 400131, Russia. Tel.: +7-8442-39-10-48, E-mail: niimmp@mail.ru ORCID: https://orcid.org/0000-0002-8683-8159

Svetlana E. Bozhkova, Candidate of biological sciences, Docent, Department of Food Production Technologies, Volgograd State Technical University. 28 Lenin avenue, Volgograd, 400005, Russia. Tel: +7-8442-24-87-00, E-mail: bozhkova@mail.ru

ORCID: https://orcid.org/0000-0001-9992-3515

Anna R. Nichiporova, Student, Faculty of Food Technology, Volgograd State Technical University. 28 Lenin avenue, Volgograd, 400005, Russia. Tel: +7-8442-24-87-00, E-mail: tpp@vstu.ru

ORCID: https://orcid.org/0000-0002-5803-5690

Yuri D. Danilov, Candidate of technical sciences, Junior Researcher, Department of Production and Processing of Livestock Products, Volga Region Scientific Research Institute of Meat-and-Milk Production and Processing. 6 Rokossovsky str., Volgograd, 400131, Russia. Tel.: +7-844239-10-48, E-mail: yuriy.daniloff.2011@mail.ru

ORCID: https://orcid.org/0000-0001-6157-4479

* corresponding author

Marina I. Slozhenkina, Doctor of biological sciences, Corresponding Member of the Russian Academy of Sciences, Director, Volga Region Scientific Research Institute of Meat-and-Milk Production and Processing. 6 Rokossovsky str., Volgograd, 400131, Russia. Tel.: +7-8442-39-10-48, E-mail: niimmp@mail.ru

ORCID: https://orcid.org/0000-0001-9542-5893

Evgeniya A. Romanenko, Applicant, Volga Region Scientific Research Institute of Meat-and-Milk Production and Processing. 6 Rokossovsky str., Volgograd, 400131, Russia. Tel.: +7-8442-39-10-48, E-mail: niimmp@mail.ru

ORCID: https://orcid.org/0000-0002-6429-8016

All authors bear responsibility for the work and presented data.

All authors made an equal contribution to the work.

The authors were equally involved in writing the manuscript and bear the equal responsibility for plagiarism.

The authors declare no conflict of interest. 